\title{
SAMOTNOŚĆ JAKO MISTYCZNA CIEMNOŚĆ. ŚW. JAN OD KRZYŻA I BL. MATKA TERESA Z KALKUTY
}

\begin{abstract}
„Straszliwa samotność"
Jan od Krzyża i Matka Teresa z Kalkuty - ci święci w różnych okolicznościach życia dali się poprowadzić Bogu drogą, która z perspektywy teologicznej jawi się jako „noc ciemna”. „Człowiek, który ją przechodzi” - pisze znawca problemu, ojciec Sergiusz Niziński - „nie rozumie, że jest to proces zbliżający go do Boga, gdyż subiektywnie wydaje mu się, że jest przez Boga odrzucony"1. „Noc ciemna” opisana przez świętego Jana od Krzyża została, jako kategoria mistyczna, wprowadzona przez Jana Taulera. Nie mamy wątpliwości, że święty Jan od Krzyża doświadczył w swym życiu „nocy ciemnej”. Nie wszyscy natomiast żywią tę pewność w odniesieniu do Matki Teresy z Kalkuty. W tym względzie ona sama nie ułatwia nam odbioru swego życia i dzieła. Mówi i pisze wiele o przeżywanych ciemnościach duchowych, jednakże stara się to czynić tak, żeby raczej nas przekonać, iż nie znajduje się $\mathrm{w}$ promieniowaniu Boga.

To, co nas podtrzymuje $\mathrm{w}$ odmiennym przekonaniu podczas lektury jej Prywatnych pism, to powracanie do doświadczenia dotknięcia przez Boga, wyrażone w słowach: „Pójdź, bądź moim światłem”, i - mimo odczuwanego zobojętnienia Boga wobec niej - ślub, który uczyniła: być zawsze Mu posłuszną. To są jej drogowskazy w „nocy ciemnej”, do których się odwołuje
\end{abstract}

${ }^{1}$ S. Niziński, Edyta Stein: ofiara holokaustu czy mistrzyni przeżywania epokowej nocy ludzkości?, [w:] Św. Teresa Benedykta od Krzyża (Edyta Stein) - Kobieta i Karmelitanka Bosa - Patronką Europy, Poznań 2001, s. 84-85. 
w różnych okolicznościach: „moje postanowienie z rekolekcji było to samo: «Tak» z całego serca dla Boga. Wielki «Uśmiech» dla wszystkich"2.

Stąd rejestrowane przez Matkę Teresę poczucie „straszliwej samotności” i odrzucenia przez Boga, jakich doświadczała, wprowadzają nas w zwątpienie co do jej mistycznej drogi. Z drugiej jednak strony owe drogowskazy pozwalają podążać za nią w nadziei na spotkanie z Bogiem:

Byłam bliska powiedzenia - Nie. Tak bardzo było ciężko. Ta straszliwa tęsknota ciągle rośnie - i czuję, jakby któregoś dnia coś we mnie miało się załamać - i wtedy ta ciemność, ta samotność, to poczucie straszliwego osamotnienia [podkr. A.G.]. Niebo od każdej strony jest zamknięte ${ }^{3}$.

Zmagania Matki Teresy z ciemnością i samotnością potęgują się, aż do punktu kulminacyjnego, zdawałoby się - przesądzającego o jej załamania i przeświadczeniu o byciu odrzuconą przez Boga:

Kazał mi Ojciec pisać - Po prostu nie potrafię znaleźć słów, by cokolwiek wyrazić. Nie wiem, dlaczego tak jest - chcę powiedzieć - a mimo to nie znajduję słów, by wyrazić swój ból. Niech Ojciec nie pozwoli, bym Ojca wprowadziła w błąd. - Niech mnie Ojciec zostawi - samą. - Bóg musi chcieć ode mnie tej "samotności” [podkr. A.G.]. Proszę o modlitwę. Mimo wszystko - chcę kochać Boga za to, co mi zabiera. On zniszczył we mnie wszystko. Proszę o modlitwę. Spróbuję mówić podczas spowiedzi albo po niej - jeśli się nie obawia Ojciec, że będę Ojca wprowadzała w błąd4

Jak pisze kierownik duchowy Matki Teresy z Kalkuty - ojciec Joseph Neuner:

Była to po prostu noc ciemna, którą znają wszyscy mistrzowie życia duchowego choć nigdy nie zetknąłem się z tym, by była ona tak głęboka i by trwała przez tak wiele lat, jak to było u niej [Matki Teresy - przyp. A.G.]. Można to przetrwać jedynie w pewności ukrytej Bożej obecności i zjednoczenia z Jezusem... [podkr. A.G.] ${ }^{5}$

Pragnienie Boga jest busolą w nocy ciemnej Matki Teresy. Jej poddanie się Bogu, bez względu na okoliczności, i przyjęcie ciemności są także gwarancją goszczenia Go w jej sercu. Dlatego też Matka Teresa po długim milczeniu (po 11 latach trwania nocy ciemnej) powie: „Zaczęłam kochać tę

2 Matka Teresa z Kalkuty, Pójdź, bądź moim świattem. Prywatne pisma „Świętej z Kalkuty”, tłum. M. Romanek, Kraków 2008, s. 298.

${ }^{3}$ Ibidem, s. 276.

${ }^{4}$ Ibidem, s. 262 (list Matki Teresy do ojca Picachy'ego SJ z 3 września 1959 r.).

${ }^{5}$ Ibidem, s. 292. 
ciemność - bo teraz wierzę, że jest ona częścią, bardzo małą cząstką ciemności i bólu Jezusa na ziemi"6.

To przekonanie pozwala jej na podjęcie ważnej decyzji dla wewnętrznego wzrastania - praktykowanie miłości, a nie refleksyjne skupianie się na sobie: „Nie wierzę, Ojcze” - powie ojcu Neunerowi - „w [sens] takiego ciągłego grzebania we własnym życiu duchowym - poprzez długie i częste odwiedziny i rozmowy"7. Przekonanie to świadczy już o długiej drodze duchowej, którą przeszła. Takie samorozpoznanie się duszy jest pewnym progiem, który przekraczają ci, co doświadczają, mimo przeżywanych duchowych oschłości, pewność ukrytej Bożej obecności. Jest to określona faza, stan nocy ciemnej ducha.

\section{"Czysty Jan od Krzyża"}

Duchowy rozwój Matki Teresy z Kalkuty porównuje się czasami z drogą na Górę Karmel św. Jana od Krzyża. Czasami, bo pamiętamy przecież nagonkę prasową, która przedstawiała "Świętą z Kalkuty” w atmosferze skandalu religijnego. Jej domniemane oszustwo wiary wstrząsnęło ludźmi na całym świecie, ludźmi o różnych opcjach religijno-światopoglądowych, dla których - jako noblistka, ale nie tylko - była wielkim autorytetem religijnym i moralnym. Uważna lektura jej Prywatnych Pism i skupienie się na całości jej „dzieła” zdecydowanie oddalić muszą wspomniane oskarżenia.

Matka Teresa znała dzieła św. Jana od Krzyża. Wielokrotnie w swej korespondencji dawała wyraz pełni duchowego zachwytu i uznania dla nich. „Właśnie czytam jego [św. Jana od Krzyża - przyp. A.G.] dzieła. Jak cudownie pisze on o Bogu", „dzieła św. Jana od Krzyża zdają się książkami, które jestem w stanie trochę zrozumieć, i czasami przynoszą mi radość - jego pisma wzbudzają we mnie głód Boga..."8. Niektórzy komentatorzy życia i pism Matki Teresy - np. ojciec Brian Kolodiejchuk - podkreślają ten właśnie fakt:

Jest rzeczą znamienną, że jej uwagę przykuwało nie to, jak hiszpański mistyk po mistrzowsku opisywał wewnętrzne oczyszczenie podczas „nocy ciemnej”, lecz raczej wszystko to, co miał do powiedzenia o Bogu. Dobrze znała jego myśl, a mimo to nie nazywała własnego cierpienia „nocą ciemną". Miała przeczucie, obecnie potwier-

\footnotetext{
${ }^{6}$ Ibidem.

7 Ibidem, s. 293.

8 Ibidem, s. 297 i 360.
} 
dzone przez kierownika duchowego, że mimo podobieństw, te dwa rodzaje cierpienia mają różny cel9 ${ }^{9}$.

Natomiast ojciec Albert Huart, jezuita z prowincji kalkuckiej, pisze:

Matka przyszła [...] porozmawiać o straszliwej nocy panującej w jej duszy. Nie była to jakaś faza przejściowa, ale trwało to od lat. Od razu uderzyło mnie to, co dodała do opisu tej bolesnej i utrzymującej się nocy [...]: „Ojcze, zdaję sobie sprawę, że kiedy otwieram usta i mówię do sióstr i do [innych] ludzi o Bogu i o Bożym dziele, daje im to światło, radość i odwagę. Ale ja nic z tego nie mam. W środku wszystko jest ciemne i [mam] poczucie, że jestem całkowicie odcięta od Boga". Dla mnie brzmiało to jak czysty Jan od Krzyża [podkr. A.G.]10.

Nie ma potrzeby zastanawiać się, który z komentatorów ma rację. Rzecz bowiem jest głębszej natury. Ważne jest natomiast oddalenie zarzutów co do niewiary i religijnego kłamstwa Matki Teresy, by możliwe było pozostanie w promieniowaniu jej świętości. Wydobycie z jej drogi duchowej typowych elementów mistycznej „nocy ciemnej” pozwala utrzymać pogląd, że „Święta z Kalkuty” przechodzi właśnie „noc ciemną”, co uprawnia do nazywania ją wręcz „świętą od ciemności"11.

\section{Indywidualne znamiona mistycznej samotności}

Typowe elementy „nocy ciemnej” można wydobyć z drogi św. Jana od Krzyża lub odwołując się do innych mistyków. Pozostańmy przy świętym, którego z radością czyta Matka Teresa. Zacytujmy niewielki fragment jego poematu:

Bezpieczna pośród ciemności,

Przez tajemnicze schody osłoniona,

O wzniosła szczęśliwości!

W mroki ciemności, w ukrycie wtulona,

Gdy moja chata była uciszona12.

Komentarze samego autora do tej strofy pokazują „śmierć starego człowieka” poprzez wyciszenie pożądań, odczuć, namiętności. Zostają one, w tej

\footnotetext{
${ }^{9}$ Ibidem, s. 297.

${ }^{10}$ Ibidem, s. 413.

11 Ibidem, s. 415.

12 Św. Jan od Krzyża, Dzieła, red. O. Filek, tłum. B. Smyrak, Kraków 1995, s. 406.
} 
"oczyszczającej nocy”, "uśpione, umartwione i zgaszone”, co zabezpiecza duszę „od próżnej chwały, pychy, zarozumiałości, próżnej i fałszywej radości i od wielu innych tym podobnych błędów". Dusza, uwolniona od swych niedoskonałości i rzeczy niepożytecznych oraz szkodliwych, jednoczy się z Bogiem ${ }^{13}$.

Święty Jan od Krzyża uważa, że owo zaciemnienie władz naturalnych jest wręcz konieczne, aby doszło do zjednoczenia z Bogiem:

O, człowieku duchowy, gdy ujrzysz swe pożądania zaciemnione, [swe odczucia oschłe i uśpione, swe władze niezdolne do żadnego ćwiczenia wewnętrznego], nie martw się tym, lecz uważaj to za szczęście! Wtedy bowiem uwalnia cię Bóg od ciebie samego i bierze ci z rąk twoje władze. Choćbyś bowiem nie wiem jak się wysilał, nie dokonasz niczego tak doskonale i bezpiecznie, z przyczyny nieczystości i niezgrabności twych rąk, jak teraz dokonasz, gdy sam Bóg, ująwszy twe ręce, prowadzi cię jak ślepca wśród ciemności. Doprowadzi cię bowiem tam, gdzie byś ty nigdy nie doszedł z pomocą twych oczu i nóg, choćbyś się najwięcej wysilał14.

Ta samotność, która jest stanem duszy ogołoconej z wszelkich odniesień do świata ludzkiego, z wszelkich uwarunkowań zewnętrznych i wewnętrznych, a więc duszy totalnie ogołoconej, zostaje $\mathbf{u}$ Jana podniesiona do rangi najwyższej doskonałości duchowej i to ona umożliwia obdarowanie i dopuszczenie do Bożych tajemnic. W Pieśni duchowej św. Jan od Krzyża „rejestruje" stan duszy, która przechodząc różne fazy nocy ciemnej, osiąga bliskość Boga:

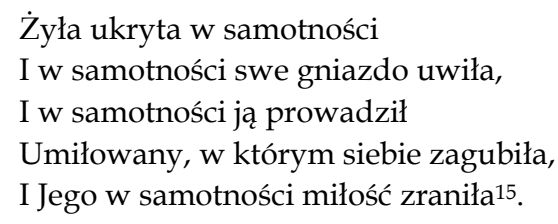

Komentarz do tej strofy wskazuje na doniosłą i kluczową rolę samotności w dochodzeniu do Boga: „Przez nią dusza dochodzi do złączenia się ze Słowem Bożym, a tym samym znajduje pełne szczęście i zadowolenie”, bo: „W tej samotności Bóg pobudza i podnosi duszę do rzeczy wyższych", a "Oblubieniec zostaje zraniony miłośnie tym, że dusza z miłości dla Niego opuściła wszystko i została w zupełnej samotności”16.

\footnotetext{
13 Ibidem, s. 490-491.

14 Ibidem, s. 492.

15 Ibidem, s. 84 .

16 Ibidem, s. 871.
} 
Święty Jan od Krzyża uznaje mistyczną samotność, osiąganą w „nocy ciemnej", nie tylko za najwyższą doskonałość, ale i za stan najwyższej szczęśliwości.

Janowe wskazówki dla człowieka duchowego w zasadzie pokrywają się z doznaniami duchowymi Matki Teresy. Pewność i bezpieczeństwo drogi, o której mówi hiszpański mistyk, odczute są również przez nią: „Co do mnie dzięki Bogu kazano nam iść za Chrystusem. - Skoro nie muszę iść przed Nim, nawet w ciemności droga jest pewna [podkr. A.G.]"17. Dalej zaś mowa jest o doświadczaniu „wyschniętego ja”: „On [Jezus - przyp. A.G.] chce mieć pewność, że wyschnie we mnie najmniejsza kropla mojego własnego ja. Zabrał też tę cotygodniową pomoc [kierownika duchowego - przyp. A.G.], więc ciemność jest tak ciemna, a ból tak wielki"18.

Matka Teresa odczuwa też stan zobojętnienia duchowego:

Przepraszam, że powiedziałam Ojcu [Neunerowi - przyp. A.G.], żeby Ojciec nie przyjeżdżał - ale naprawdę nie warto, skoro moja dusza jest po prostu jak bryła lodu. - Nie mam nic do powiedzenia19.

Przeżywa również „radości cierpienia” z uwagi na jego odkupieńczą moc, różniącą je od zwykłej działalności społecznej:

bez naszego cierpienia nasze dzieło byłoby zwykłą działalnością społeczną, bardzo dobrą i użyteczną, ale nie byłoby ono dziełem Jezusa Chrystusa, nie byłoby częścią odkupienia [...]. Dzielmy cierpienia - naszych ubogich - bo tylko przez to, że jesteśmy jedno z nimi - możemy ich odkupić, to znaczy przyprowadzić Boga do ich życia, a ich prowadzić do Boga 20 .

Te przekonania pozwalają na snucie dalszych paralel między drogą Matki Teresy i „nocą ciemną”. Jej doświadczenie określić jako „radość Nocy" i przedstawić, jak to czyni ojciec Albert Huart, w metaforze domku górskiego, którego opis przypomina „chatę uciszoną" Jana od Krzyża:

Kiedy jej [Matki Teresy - przyp. A.G.] słuchałem, w mojej wyobraźni pojawił się obraz górskiego domku skąpanego w jasnym ciepłym słońcu. Otoczonego bujną roślinnością i kwiatami, w którego wnętrzu jednakże panują ciemność i chłód²1.

\footnotetext{
${ }^{17}$ Matka Teresa z Kalkuty, op. cit., s. 301.

18 Ibidem, s. 298.

19 Ibidem, s. 307.

20 Ibidem, s. 300.

${ }^{21}$ Ibidem, s. 413; por. A. Huart SJ, Joy in the Night, „Review for Religious” 2001, nr 5
} 
Można zatem powiedzieć, że Jan od Krzyża i Matka Teresa z Kalkuty święci od Ciemności - idą razem drogą "nocy ciemnej”. Razem, ale osobno. Stąd droga ta ma indywidualne znaki. Ważne jest to, że w Matce Teresie pisma Jana „wzbudzają głód Boga”, lecz, co ważniejsze, w obu przypadkach jest to duchowa "noc ciemna”, a nie psychicznie traumatyczne przeżycie. Jest to duchowe doświadczenie, bo ten głód Boga u jednego i drugiego świętego wzbudza i przybliża do Boga, a nie oddala od Niego. Zjednoczenie z Nim, które Jan opisuje jako „dotknięcie” Boga (tak zwane toque), dotknięcie powtarzane, u Matki Teresy było wyraźne, ale jednorazowe. Codziennie praktykowana przez nią Eucharystia to zjednoczenie jednak podtrzymywała.

\section{Samotność dla Boga i z Bogiem}

Doświadczanie przez Matkę z Kalkuty tego „strasznego uczucia, że [jest] przez Niego niechciana", jest indywidualnym piętnem jej duchowej drogi. "Jeśli moja ciemność jest światłem dla jakiejś duszy - a nawet jeśli jest niczym dla nikogo - jestem całkowicie szczęśliwa - że jestem Bożym polnym kwiatem"22. Była też z Bogiem zjednoczona przez ból opuszczenia. „Mam Jego ciemność - mam Jego ból kochać i nie być kochaną"23.

Ten stan nie jest jednak dla Matki Teresy równoznaczny ze stanem Janowej szczęśliwości. Przeżywa go „dramatycznie”, odczuwa bardzo indywidualnie, porównuje się z innymi misjonarkami, które, jak się jej wydaje, doznają zjednoczenia z Bogiem: „Widzę jak na moich oczach Siostry kochają Boga - są tak bardzo blisko Niego - codziennie tak bardzo się do Niego upodabniają - a ja, Ojcze - po prostu jestem «sama» - pusta - pominięta po prostu niechciana [podkr. A.G.]". I mimo że trwa przy Bogu i razem z Bogiem na mocy uczynionego ślubu i doświadczania "jednoczącej” szczęśliwości innych, wyznaje: "A przecież to tak boli być samotną dla Boga" [podkr. A.G.] ${ }^{24}$.

Pisma Matki Teresy, rejestrując stany samotności, wprowadzają więc inne niż u św. Jana od Krzyża odcienie w jej doznawaniu, a trzeba też zauważyć, że, jak stwierdza jej biograf: „oddzielenie od Boga i oddzielenie od ludzi - to był jej codzienny los"25. Ten „ból samotności”, wbrew psychicznym (indywidualnym) i wręcz fizycznym (społecznym) doznaniom, Matka Teresa mistycznie przezwycięża, traktując go jako „pocałunek Jezusa":

\footnotetext{
${ }^{22}$ Matka Teresa z Kalkuty, op. cit., s. 289.

${ }^{23}$ Ibidem, s. 305.

24 Ibidem, s. 302-303.

${ }^{25}$ Ibidem.
} 
Cierpienie, ból, porażka - to nic innego jako pocałunek Jezusa, znak, że tak bardzo się zbliżyłaś do Jezusa na Krzyżu, że może Cię pocałować. - Więc, moje dziecko, ciesz się. [...] Nie zniechęcaj się [...] więc uśmiechnij się znowu. [...] Jest to dla Ciebie najpiękniejszą szansą, byś stała się w pełni i całkowicie cała dla Jezusa26.

Doświadczenie samotności Matki Teresy w „nocy ciemnej”, jak i doświadczenie cierpień i ubóstwa innych ludzi stają się podstawą jej rad dla innych Sióstr, by odkrywały w tych stanach obecność Chrystusa i szansę na zjednoczenie się z Nim, bo, jak przekonuje:

Wolą Ojca była ta straszliwa samotność w Ogrodzie [Getsemani], na Krzyżu. On był całkowicie sam. Jeśli jesteśmy prawdziwymi naśladowcami Jezusa, my także musimy doświadczać samotności Chrystusa. - On pocił się krwią (zob. Łk 22, 39-46). Tak trudne było dla Niego przejście upokorzeń Męki [podkr. A.G.]27.

Święty Jan od Krzyża znosi inne cierpienie odrzucenia - odrzucenia przez wspólnotę zakonną - mimo wielkiej miłości do Boga świadczonej reformatorskimi działaniami na rzecz odnowy reguły karmelitańskiej. To z uwagi na nie odczuwa miłość Boga, nie będąc kochanym przez tych, których „wspólnotowo” kochał, a którzy go odrzucili.

Można powiedzieć, że cierpienie Matki Teresy i Jana od Krzyża jest prawdą prowadzącą do Boga przez "noc ciemną". I jest to zgodne z odkrywczą intuicją św. Teresy z Àvila: prawda, która cierpi, nigdy nie ginie. Trzeba też zaznaczyć, że Matka Teresa dostrzegała Boga w prozie życia, „na ulicy”, w twarzy cierpiącego biedaka, "najuboższego z ubogich”. Jan od Krzyża również cierpiał z ubogimi, jednakże utrwalił swą "noc ciemną" $\mathrm{w}$ poetyckim i kontemplacyjnym zarazem uniesieniu. Poza tym, o czym warto pamiętać, tę noc „śpiewa dusza będąca już w stanie doskonałości, czyli w zjednoczeniu miłości z Bogiem"28, a nie dusza dążąca do niej.

Stąd św. Jan od Krzyża może spisać już wiele wskazówek i udzielić wielu rad człowiekowi „postępującemu” na drodze ku doskonałości, której celem jest mistyczne zjednoczenie z Bogiem. Szczególnie owocne na niej jest twórcze, to znaczy pełne wiary i pobożne przeżywanie samotności, i to zarówno na pielgrzymim szlaku, jak i w trakcie modlitwy.

Bardzo często udziela Bóg łask przez obrazy znajdujące się w miejscach ustronnych i samotnych. Bywa tak dlatego, że przez trud, jakiego wymaga dojście na te miejsca, wzrasta uczucie i siła pobożności. Następnie dlatego, że ludzie usuwają się wtedy od

\footnotetext{
${ }^{26}$ Ibidem, s. 382.

27 Ibidem, s. 393.

${ }_{28}$ Por. św. Jan od Krzyża, op. cit., s. 407.
} 
zgiełku świata, aby się lepiej pomodlić, jak to czynił Pan nasz Jezus Chrystus (Mt 14,23; Łk 6,12).

Kto więc odbywa pielgrzymkę, dobrze czyni, jeśli ją odbywa samotnie, chociażby w innym, niż zwyczajnie, czasie. Nigdy bym zaś nie radził podejmować wtedy pielgrzymki, gdy idzie wielki tłum ludzi. Wówczas bowiem ludzie wracają bardziej roztargnieni, niż byli przedtem. Są również tacy, którzy idą z pielgrzymką raczej dla rozrywki niż dla pobożności [podkr. A.G.]29.

W tak odbywanej pielgrzymce czy modlitwie dusza nie osiągnie „bez wiary i pobożności” - według rad św. Jana - „tak heroicznego i tak niezwykłego dzieła, jakim jest zjednoczenie jej z Boskim Oblubieńcem".

Musi więc oddalić się od wszystkiego i wyjść na zewnątrz, gdyż Umiłowanego może spotkać jedynie w samotności. [...] Muszą więc wszystkie władze duszy być uspokojone i czekać biernie na przyjęcie tych łask, nie mieszając się do tego swym nieudolnym działaniem i niską skłonnością -podkr. A.G.]30.

\section{"Samotność jako trąd"}

Matka Teresa, inaczej niż św. Jan, wychodziła w swej „posłudze miłości” bezpośrednio do ludzi. Przemierzała "ziemię trędowatą", żyła tak, jak żyją biedni. Ta "poszukiwaczka ludzkich śmieci”, doznając „olśnienia ubogich”, oddała się „służbie miłości”. Zwana też „menedżerem Ewangelii”, uczyniła Indie magnesem dla chrześcijan pragnących żyć Kazaniem na Górze, zamiast tylko je głosić. Jej apostolstwo okazało się skutecznym lekarstwem na trąd budzący przerażenie, niszczący rodziny. "Dotknij trędowatego swym współczuciem" - mówiła, co znaczyło właśnie - działaj. Lecz trąd to nie tylko Indie. W przekonaniu Matki Teresy to również Zachód. Samotność, jako „osiągnięcie” naszej cywilizacji, nazwała ona "zachodnim trądem” i stwierdziła, że wymaga on intensywnej terapii. Odwiedzanie samotnych, "posługiwanie im bez odpłaty" to lekarstwo, które zawiera hodowany w jej Zgromadzeniu owoc miłości. Owoc, który przemienia serca z kamienia, ale i skutecznie leczy zapomnianych. Mistrzyni Miłosierdzia uczyła i nadal uczy w ten sposób współczucia i zachęca do wspaniałomyślności. Uczy ekumenicznego podejścia do "trędowatych" wszelkiego rodzaju, wszelkich ras, wyznań, narodowości, płci i wieku. Niesie świadectwo miłości, a nie nawraca. To świadectwo, będące darem, przynosi więcej pożytku obdarzającemu

\footnotetext{
29 Ibidem, s. 385.

${ }^{30}$ Ibidem, s. 487-488.
} 
niż obdarowanemu. Taka jest, według niej, ,"logika daru” dawanego w miłości.

Jej rady na przezwyciężanie osamotnienia innych i swej indywidualnej samotności pozwalają zamienić „mistyczny pocałunek Jezusa” na „pocałunek trędowatego". To heroiczne przezwyciężanie siebie i bezgraniczna miłość ubogich uczą czynnego przekraczania samotności, przekraczania jej w miłosiernej praktyce:

Im bardziej odrażająca praca, tym głębsza jest nasza wiara, tym większa radość poświęcenia. To, że czujemy odrazę, jest naturalne, kiedy jednak potrafimy ją przezwyciężyć z miłości do Jezusa, możemy stać się świętymi. Zdarzało się często w życiu świętych, że heroiczne przezwyciężenie czegoś, co budziło odrazę, stawało się kluczem do wielkiej świętości. Miało to miejsce w przypadku świętego Franciszka z Asyżu, który, napotkawszy trędowatego - a był strasznie oszpecony - cofnął się, ale natychmiast przezwyciężył się i ucałował oszpeconą twarz. I wtedy ogarnęła Franciszka niewypowiedziana radość. Stał się panem samego siebie, a trędowaty odszedł, wielbiąc Boga za uzdrowienie ${ }^{31}$.

Na drodze Matki Teresy „pocałunek trędowatego", rozumiany jako czynne przezwyciężanie samotności, jest więc i darem mistycznie spotkanego Jezusa, i darem dla innych samotnych. Jest przynoszącym wymierne skutki sposobem walki z samotnością, czyli „trądem czasów współczesnych" - trądem, którego przyczyną jest „utrata Boga” i brak wewnętrznej walki o odzyskanie Go. Matka Teresa walczyła niejako podwójnie, z własną samotnością i samotnością innych, próbując ujrzeć Boga przez siebie - dla nich. W swym Liście do Jezusa posuwała się i do bluźnierstw, i do błagania o Jego przyjście, w imię wieczności dla siebie i innych:

Mówi się, że ludzie w piekle cierpią męki wieczyste z powodu utraty Boga - przeszliby przez te wszystkie cierpienia, gdyby mieli choćby maleńką nadzieję, że posiądą Boga. - Czuję w duszy po prostu ten straszliwy Ból z powodu utraty - Boga, który mnie nie chce - Boga, który nie jest Bogiem - Boga, który naprawdę nie istnieje (proszę, Jezu, wybacz moje bluźnierstwa - kazano mi pisać wszystko) [...]. Błagam Cię tylko o jedno - proszę, nie zadawaj sobie trudu, by wrócić szybko. - Jestem gotowa czekać na Ciebie przez całą wieczność32.

Samotność to nie jest "przegrana Boga”, to walka o spotkanie Go, walka o Jego przyjście - tego uczą nas mistycy.

\footnotetext{
31 Ibidem, s. 20-21.

32 Ibidem, s. 263 i 265.
} 
Solitude as a mystic darkness.

Saint John of Cross and Blessed Mother Teresa of Calcutta

\section{Summary}

The "dark night" - painful feeling being abandoned by God - was experienced by many masters of spiritual life, by saint John of Cross as well as by blessed Mother Teresa, as is shown in her memoirs. Authoress claims that, paradoxically, this apparently declining experience is just a stage that has to be passed in order to achieve fullness of mystic insight and spiritual growth. Doubts, grief, lack of power and will - all this feelings are not the symptoms of spiritual collapse but a steps on a way into holiness. The God is the one who gives the power to overcome typically human weaknesses and crises (solitude, isolation, adversities). 